\title{
GEMAR QUR'AN "GERAKAN MASYARAKAT BELAJAR AL-QUR'AN" DI DESA KALOLING KABUPATEN BANTAENG
}

\section{GEMAR QUR'AN "COMMUNITY MOVEMENT TO LEARN THE QUR'AN" IN KALOLING VILLAGE, BANTAENG REGENCY}

\author{
Santi Sarni \\ Sekolah Tinggil Ilmu Islam dan Bahasa Arab (STIBA) Makassar \\ santisarni@stiba.ac.id \\ Jujuri Perdamaian Dunia \\ Sekolah Tinggil Ilmu Islam dan Bahasa Arab (STIBA) Makassar \\ jujuri@stiba.ac.id \\ Nurfiah \\ Sekolah Tinggi Islam dan Bahasa Arab (STIBA Makassar) \\ nurfiah@stiba.ac.id
}

\begin{tabular}{|c|c|}
\hline Keywords : & ABSTRACT \\
\hline $\begin{array}{l}\text { Community Service, Gemar } \\
\text { Qur'an, Kaloling Village, } \\
\text { Learn the Qur'an, }\end{array}$ & $\begin{array}{l}\text { Community service program was conducted in Kaloling Village, } \\
\text { Bantaeng Regency (200 km from Makassar City). Kaloling village } \\
\text { has the characteristics of a religious community, hardworking, open- } \\
\text { minded, and supported by educational facilities available at all } \\
\text { levels of education. However, kaloling villagers do not have the } \\
\text { opportunity to study the Qur'an intensively because of their daily } \\
\text { routine and busy work. therefore, the activities of KKN STIBA } \\
\text { Makassar in Bantaeng Regency are focused on community } \\
\text { development programs to study the Qur'an, called "Gemar Qur'an". } \\
\text { In its implementation, PkM began by using soar analysis approach } \\
\text { to the needs of local community empowerment. From the analysis, } \\
\text { the Qur'an learning movement program consists of two activities, } \\
\text { Tahsinul Qiro'ah (improvement of qur'an reading) for Muslims and } \\
\text { Daurah Memorization and muroja'ah Al-Qur'an for children. the } \\
\text { result of this PkM activity is formed several learning groups of the } \\
\text { Qur'an consisting of various age levels for tahsinul Qiro'ah } \\
\text { activities. Other results are increased motivation and enthusiasm of } \\
\text { children in learning, as well as playing and having fun while } \\
\text { learning. }\end{array}$ \\
\hline \multirow{2}{*}{$\begin{array}{l}\text { Kata kunci : } \\
\text { Pengabdian Masyarakat, Gemar } \\
\text { Qur'an, Desa Kaloling, Belajar } \\
\text { Al-Qur'an, }\end{array}$} & ABSTRAK \\
\hline & $\begin{array}{l}\text { Program pengabdian masyarakat dilaksanakan di Desa Kaloling } \\
\text { terletak di bagian tenggara Kabupaten Bantaeng dengan jarak } 200 \\
\text { km dari Kota Makassar. Dengan karakteristik masyarakat yang } \\
\text { religius, pekerja keras dengan pemikiran terbuka, serta didukung } \\
\text { dengan adanya fasilitas pendidikan yang cukup di semua strata } \\
\text { pendidikan, tetapi tidak berkesempatan mempelajari Al-Qur'an } \\
\text { secara intensif dikarenakan oleh rutinitas pekerjaan sehari-hari. } \\
\text { Dalam pelaksanaannya, PkM ini diawali dengan menggunakan } \\
\text { pendekatan analisis SOAR atas kebutuhan pemberdayaan } \\
\text { masyarakat setempat. Dari analisis tersebut lahirlah program }\end{array}$ \\
\hline
\end{tabular}


Gerakan Cinta Al-Qur'an yang terdiri atas 2 kegiatan yaitu Tahsinul Qiro'ah atau perbaikan bacaan yang ditujukan untuk muslimah, dan Daurah Menghafal dan muroja'ah hafalan untuk anak-anak. Di antara hasil PkM ini adalah, untuk kegiatan Tahsinul Qiro'ah, terbentuk beberapa kelompok belajar Al-Qur'an yang terdiri dari beberapa jenis usia, dari yang remaja sampai ibu-ibu yang sudah memiliki banyak anak. Adapun untuk kegiatan Daurah Menghafal, hasilnya adalah meningkatnya motivasi dan antusias anak-anak dalam belajar, serta bermain dan bergembira sambil belajar.

Diterima: 20 April 2021; Direvisi: 10 Mei 2021; Disetujui: 25 Mei 2021; Tersedia online: 18 Juni 2021

How to cite: Santi Sarni, Jujuri Perdamaian Dunia, Hijrayanti Sari. Gemar Qur'an, "Gerakan Masyarakat Belajar di Desa Kaloling, Kabupaten Bantaeng", WAHATUL MUJTAMA': Jurnal Pengabdian Masyarakat Vol 2, No.1 (Juni 18, 2021): 40-48. doi: https://doi.org/10.36701/wahatul.v2i1.343

\section{PENDAHULUAN}

Desa Kaloling terletak di bagian tenggara Kabupaten Bantaeng dengan jarak 200 km dari Kota Makassar. Secara administrasi, Desa Kaloling termasuk dalam, Kecamatan Gantarang Keke Kabupaten Bantaeng Provinsi Sulawesi Selatan. Desa Kaloling terdiri atas 6 dusun, yaitu Dusun Borongjatia, Borongkalukua, Kaloling, Lele Lompo, Erasayya dan Jampea. Sumber daya alam yang diandalkan di Desa Kaloling ialah melalui hasil pertanian adalah padi dan jagung, sedangkan untuk hasil perkebunan adalah kakao. Desa Kaloling memiliki potensi untuk pengembangan peternakan di antaranya adalah kambing, kuda, ayam kampung dan sapi.

Kondisi hunian di Desa Kaloling didominasi oleh rumah-rumah panggung. Namun demikian, sejalan dengan perubahan pola pikir masyarakat serta perkembangan bahan bangunan, banyak di antara penduduk desa yang kini membangun rumah dari kontruksi baru dan meninggalkan pola berhuni dengan rumah panggung. Desa Kaloling memiliki gedung yang berkenaan dengan segala urusan pemerintahan dan sosial secara terstruktur seperti kantor desa, balai desa dan puskesos (pusat kesejahteraan sosial) bertempat dalam satu gedung dan kompleks kantor desa.

Pendidikan di Desa Kaloling meliputi gedung sekolah dengan tingkat pendidikan dimulai dari TK, SD, SMP, SMA dan perguruan tinggi atau yang sederajat untuk mewadahi proses kegiatan belajar mengajar. Tempat yang menunjang kegiatan peribadatan dan keagamaan, secara keseluruhan masyarakat Desa Kaloling memeluk agama Islam sehingga untuk memfasilitasi kegiatan atau 
urusan keagamaan masjid dibangun secara merata di seluruh desa. Jumlah masjid di Desa Kaloling berjumlah 11 masjid terbagi di setiap dusun ${ }^{1}$.

Secara umum karakteristik masyarakat Desa Kaloling bercirikan religius, pekerja keras dengan pemikiran terbuka yang didukung adanya fasilitas pendidikan yang cukup di semua strata pendidikan. Hanya dikarenakan kesibukan bekerja sehari-hari sehingga kesempatan untuk belajar Islam dan Al-Qur'an cenderung kurang diprioritaskan. Oleh karena itu, hal inilah yang menjadi alasan bagi mahasiswa KKN untuk membuat program Gerakan Cinta Qur'an. Adapun tujuannya ialah mendekatkan Al-Qur'an ke masyarakat Desa Kaloling secara umum, ke muslimah dan anak-anak secara khusus.

Berdasarkan alur narasi di atas dipahami bahwa tujuan dari pelaksanaan pengabdian kepada masyarakat $(\mathrm{PkM})$ yang hendak dilakukan oleh pihak Sekolah Tinggi Ilmu Islam dan Bahasa Arab (STIBA) Makassar adalah:

1. Menumbuhkan kesadaran sosial mahasiswa dalam berdakwah berbasis ilmu pengetahuan Islam yang telah diperoleh selama di STIBA Makassar.

2. Mengembangkan kompetensi dakwah lapangan mahasiswa STIBA Makassar.

3. Mengamalkan tri dharma perguruan tinggi bagi Dosen Pembimbing Lapangan (DPL) pada pilar pengabdian kepada masyarakat.

4. Mengembangkan eksistensi STIBA Makassar sebagai perguruan tinggi berbasis pengkaderan ulama dan organisatoris yang bermanfaat kepada masyarakat.

Pada pelaksanaan KKN ini, pada dasarnya menggunakan metode yang diawali dengan melakukan survei lapangan dengan menggunakan instrumen buatan mandiri kemudian dilanjutkan dengan prosesi analisis SOAR. Tujuannya adalah untuk mengidentifikasi masalah yang terjadi di masyarakat. Berdasarkan survei lapangan maka didapatkan sebagai berikut:

1. Strength, masyarakat Desa Kaloling berkarakter religius, etos kerja tinggi, dan pemikiran terbuka. Sedangkan mahasiswa STIBA Makassar telah dibekali pemahaman agama yang baik, memiliki keterampilan dakwah dan terlatih untuk pengajaran Al-Qur'an untuk berbagai lapisan usia.

2. Opportunities, dukungan dan kerjasama dari masyarakat.

3. Aspiration, gerakan cinta Al-Qur'an menjadi program desa binaan.

4. Result, masyarakat Desa Kaloling dekat dan cinta dengan Al-Qur'an.

Dari prosesi analisis singkat di atas, dicetuskanlah program Gerakan Cinta Al-Qur'an yang terdiri atas 2 kegiatan yaitu Tahsinul Qiro'ah atau perbaikan bacaan yang ditujukan untuk muslimah, dan daurah menghafal dan muroja'ah hafalan untuk anak-anak.

\footnotetext{
${ }^{1}$ Profil Desa Kaloling
} 
PkM tentang Al-Qur'an yang relevan dengan KKN ini sebenarnya sudah cukup banyak, di antaranya:

1. PkM yang dilaksanakan oleh Ismail dalam bentuk program pengabdian yang dilaksanakan pada TK-TPA Al-Qur'an At-Taqwa Kelurahan Kambiolangi Kecamatan Alla bertujuan untuk: (a) mengidentifikasi jumlah santri di Kelurahan Kambiolangi Kecamatan Alla Kabupaten Enrekang; (b) mengetahui efektivitas metode IQRO dalam memberantas buta aksara Al-Qur'an pada santri TK-TPA At-Taqwa di Kelurahan Kambiolangi Kecamatan Alla Kabupaten Enrekang. Pendekatan yang dilakukan pada kegiatan PkM ini adalah pendekatan langsung, yaitu langsung dibaca tanpa dieja, langsung berhadapan atau tatap muka. Dari hasil pengabdian diperoleh simpulan narasi bahwa (a) Masih tingginya jumlah angka buta aksara Al-Qur'an pada anakanak di Kelurahan Kambiolangi Kecamatan Alla Kabupaten Enrekang; (b) Faktor penyebab dari tingginya jumlah angka buta aksara pada anak-anak tersebut adalah lebih kepada faktor intern atau pribadi saja yaitu kurangnya minat dan motivasi untuk terus belajar Al-Qur'an; (c) Metode IQRO merupakan metode yang dianggap efektif digunakan dalam rangka memberantas buta aksara Al-Qur'an pada anak-anak ${ }^{2}$.

2. PkM yang dilaksanakan oleh Aswar, dkk., yang bertujuan untuk meningkatkan kompetensi, akhlak, dan adab anak-anak usia sekolah dasar di Kelurahan Leang-Leang melalui pelaksanaan program kegiatan yang bertajuk "Festival Anak Saleh" (FAS). Acara tersebut diselenggarakan oleh mahasiswa KKN angkatan III STIBA Makassar yang dibimbing langsung oleh Dosen Pembimbing Lapangan (DPL). Adapun bentuk-bentuk perlombaan dalam FAS meliputi Lomba Azan, Musabaqah Tilawatil Quran (MTQ), Musabaqah Hifdzil Qur'an (MHQ), Cerdas Cermat Islam (CCI), dan Da'i Cilik. Metode pelaksanaan kegiatan didahului dengan melakukan analisis kebutuhan anakanak usia sekolah dasar di sekitar lokasi KKN, lalu kemudian dibuat perencanaan kegiatan, pelaksanaan, dan evaluasi serta follow up kegiatan. Hasil dari PkM ini adalah anak-anak usia sekolah dasar telah memiliki pengetahuan Islam dasar, hafalan surah surat pendek, dan doa-doa harian, serta antusias dalam mempelajari Al-Qur'an ${ }^{3}$.

3. PkM yang dilaksanakan oleh Hasanah dan kawan-kawan bertujuan untuk memberikan pembinaan kepada mitra tentang manajemen pembelajaran dan

\footnotetext{
${ }^{2}$ Stkip Muhammadiyah Enrekang, "Pelatihan Dan Pengajaran Baca Tulis Al- Qur' an Pada TK -TPA At-Taqwa Dalam Mengatasi Buta Aksara Qur' an Di Kelurahan Kambiolangi Ismail” 1, no. 1 (2019): 21-27.

${ }^{3}$ Aswar Aswar and Rosmita Rosmita, "Festival Anak Saleh Di Desa Leang-Leang Kabupaten Maros," WAHATUL MUJTAMA': Jurnal Pengabdian Masyarakat 1, no. 1 (2020): 54-66, https://doi.org/10.36701/wahatul.v1i1.137.
} 
sosialisasi tahsin tilawah Al-Qur'an kepada masyarakat yang ditujukan kepada ibu-ibu di sekitar lokasi pengabdian. Penyusunan jadwal kegiatan merupakan awal, yang kemudian dilanjutkan dengan pembinaan dan motivasi, pelatihan manajemen pembelajaran, evaluasi program, sosialisasi dan evaluasi akhir. Hasil dari PkM ini menunjukkan peserta ibu-ibu kemampuan tilawah AlQur'an yang memadai. Adapun kegiatan PkM akan dipublikasikan dalam jurnal ilmiah ilmiah dan media cetak, sehingga dapat diketahui oleh masyarakat luas ${ }^{4}$.

Perbedaan dari ketiga PkM di atas dengan PkM penulis adalah dari sisi gerakan cinta Al-Qur'an ini menyentuh seluruh lapisan usia, dengan menggunakan pendekatan sesuai dengan usianya masing-masing.

\section{PEMBAHASAN}

\section{Tahsin Qiro'ah Al-Qur'an (Perbaikan Bacaan Al-Qur'an)}

Tujuan dari kegiatan ini untuk menanamkan kembali kecintaan masyarakat kepada Al-Qur'an, memperkenalkan hukum-hukum bacaan Al-Qur'an serta memperbaiki kesalahan dalam membacanya. Pada dasarnya kegiatan Tahsin Qiro'ah Al-Qur'an (Perbaikan Bacaan Al-Qur'an) adalah menyasar kaum muslimin yang sudah bisa mengaji ${ }^{5}$. Adapun langkah-langkah kegiatan sebagai berikut:

1. Membuat broadcast tentang keutamaan Al-Qur'an dan mengajak untuk belajar Al-Qur'an.

2. Memasukkan peserta yang berminat ke grup umum.

3. Membagi peserta berdasarkan waktu lowong masing-masing.

4. Memberikan beberapa kelompok kepada peserta KKN yang lain.

5. Menjalankan kelompok setiap pekan.

Pengalaman menarik dari program ini adalah setelah broadcast disebar ke grup-grup muslimah, ternyata peserta mencapai 70-an dari berbagai jenis umur dan dari asal yang beragam. Bahkan beberapa peserta dari luar Sulawesi seperti Jawa sangat antusias untuk memperbaiki bacaan Al-Qur'an. Begitu juga ibu-ibu rumah tangga yang sudah berumur bahkan memiliki 5 anak dan sedang hamil besar sangat antusias untuk masuk ke kelompok belajar tahsin. Faktor pendukung keberhasilan program ini adalah semangat para peserta dalam mengikuti kelas tashin hingga banyak yang sudah ingin langsung diperbaiki bacaannya. Adapun kendalanya

${ }^{4}$ Hasanah, Uswah, et al. "PkM Pembinaan Taman Baca Al Quran Dalam Pembelajaran Tahsin Tilawah Di Kelurahan Sari Rejo Medan Polonia." Ihsan: Jurnal Pengabdian Masyarakat 2.1 (2020): 101-111.

${ }^{5}$ Putri, Sri Ujiana, and Aswar Aswar. "Implementasi Pendidikan Masyarakat Berbasis Masjid untuk Muslimah di Desa Mattoanging Kabupaten Maros." WAHATUL MUJTAMA': Jurnal Pengabdian Masyarakat 1.2 (2020): 129-141. 
adalah beberapa peserta tidak memiliki aplikasi Zoom Meeting dan jaringan yang tidak bisa mengaksesnya. Dengan demikian, langkah solutif yang dapat ditempuh adalah mengirimkan materi via rekaman dan mengadakan perbaikan bacaan melalui grup WhatsApp.

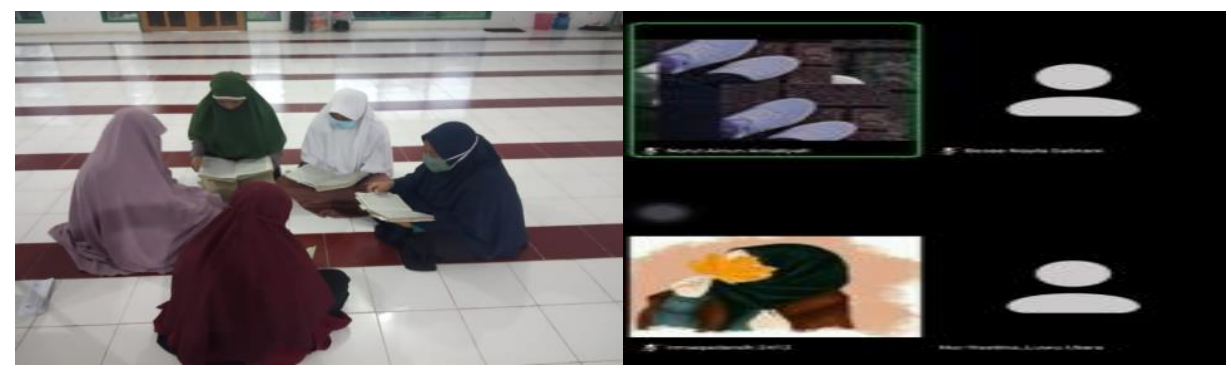

Gambar 1. Kegiatan Perbaikan Bacaan Al-Qur’an.

Hasil dari kegiatan bisa dilihat pada sebelum kegiatan di mana wawasan masyarakat seputar hukum-hukum ilmu tajwid dan yang berkaitan dengan AlQur'an masih sangat minim. Berkenaan dengannya, Iskandar dan Amirullah pun menegaskan bahwasanya kegiatan Tahsinul Qiro'ah adalah merupakan program pengajaran Al-Qur'an yang bertujuan untuk memberikan pemahaman kaidah tajwid dan makharijul huruf yang benar bagi kaum muslimin yang telah mampu membaca Al-Qur'an. Adapun setelah kegiatan berlangsung, masyarakat mulai mengetahui hal-hal yang berkaitan dengan hukum ilmu tajwid. Adapun kegiatan tahsin ini tetap berlanjut meskipun program KKN telah usai, dengan memanfaatkan teknologi komunikasi yang ada.

\section{Dauroh 10 Hari Menghafal dan Memurajaah Surah-surah Pendek}

Kegiatan ini dimulai pada tanggal 17 Maret 2021 dan berakhir pada tanggal 27 Maret 2021. Diawali dengan membuat flayer dan undangan kepada orang tua santri yang ingin mengikutsertakan anak-anaknya dalam dauroh ini. Kemudian para pelaksana kegiatan memberikan dekorasi yang menarik pada ruangan kegiatan untuk memberikan efek betah pada anak-anak. Kegiatan dibuka pada pukul 09.3011.00 WITA dengan jumlah peserta sebanyak 25 orang dengan usia yang beragam dari 4 sampai 10 tahun. Agenda hari pertama adalah perkenalan dengan cara bermain, diawali oleh mahasiswi KKN kemudian dilanjutkan oleh peserta satu per satu. Agenda berikutnya adalah menghafal surah-surah pendek dan membaca doadoa harian seperti, doa sebelum belajar, doa untuk kedua orang tua, doa untuk kebaikan dunia dan akhirat, doa sebelum dan sesudah tidur, doa masuk dan keluar masjid, doa masuk dan keluar rumah, doa masuk dan keluar wc, doa saat sakit, doa menjenguk orang yang sedang sakit, doa kelancaran berbicara, doa mensyukuri nikmat dan doa-doa harian lainnya. Di antara agenda-agenda menghafal ini,

Santi Sarni, Jujuri P. Dunia, Hijrayanti Sari. Gemar Qur'an, “Gerakan ... 
diberikan waktu untuk istirahat agar santri tidak jenuh, dan santri dapat bermain dengan mahasiswi KKN sehingga terjalin hubungan yang cukup akrab antara santri dengan mahasiswi KKN.

Selain santri yang menikmati kegiatan, para mahasiswi juga cukup menikmati kegiatan tersebut dan yang menjadi pengalaman menarik bagi mahasiswi KKN adalah menyaksikan keseruan para santri yang sangat lucu dan menggemaskan. Dengan melihat perbedaan usia para santri yang variatif sehingga tingkah laku mereka pun tampak beragam dalam mengahadapinya, dan secara tidak langsung hal inilah yang dapat mengasah kemampuan para mahasiswi. Adapun halhal yang mendukung sehingga kegiatan ini bisa berjalan dengan lancar adalah dukungan para orang tua santri yang sepenuhnya mempercayakan anak-anak mereka untuk diolah oleh para pelaksana kegiatan. Selain itu, kegiatan ini berjalan dengan sangat baik tanpa mendapatkan kendala yang cukup berarti. Adapun tujuan dan manfaat dari program menghafal Al-Qur'an adalah sebagai sarana penyetoran hafalan sekaligus perbaikan bacaan atau hafalan yang keliru, serta menambah jumlah setoran hafalan santri ${ }^{6}$.

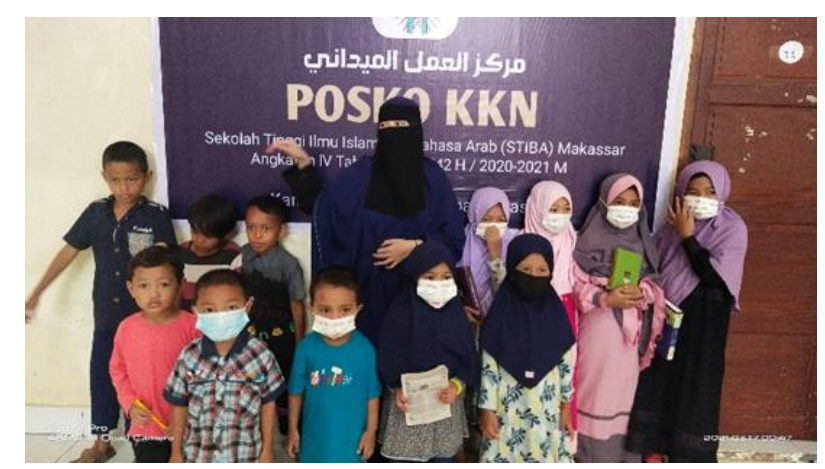

Gambar 2. Kegiatan Setelah Dauroh

Hasil kegiatan ini dapat dilihat pada perbedaan sebelum dan setelah kegiatan. Sebelum kegiatan Dauroh 10 Hari Menghafal dan Memurajaah Surahsurah Pendek tampak:

1. Ukhuwah antara para peserta dauroh (anak-anak) dengan para kakak KKN sangat kurang.

2. Ukhuwah di antara sesama peserta di sini juga masih kurang (ada beberapa yang masih belum saling mengenal nama masing-masing).

3. Beberapa dari peserta ada yang masih kurang bahkan belum hafal sama sekali doa-doa harian.

${ }^{6}$ Tempo, Rachmat Bin Badani, and Khaerul Aqbar. "Ikhtiar Mahasiswa KKN STIBA Makassar dalam Pembentukan Akhlak Qur'ani Masyarakat Desa Balassuka Kabupaten Gowa." WAHATUL MUJTAMA': Jurnal Pengabdian Masyarakat 1.1 (2020): 90-115. 
4. Belum mengetahui karakter dari setiap peserta (peserta belum membuka diri dengan pelaksana kegiatan).

5. Interaksi dan komunikasi dari mahasiswi KKN dan peserta yang belum terbangun.

Adapun setelah kegiatan, terlihat bahwa:

1. Ukhuwah antara para peserta dauroh (anak-anak) dengan para kakak-kakak KKN mahasiswi menjadi lebih kuat.

2. Ukhuwah di antara sesama peserta juga sudah menjadi lebih baik (setiap peserta sudah saling mengenal dan saling tegur sapa saat berpapasan).

3. Secara keseluruhan dari peserta sudah bisa mengetahui doa-doa harian tersebut, meski ada juga sedikit dari mereka (peserta yang msih sangat kecil usianya) yang apabila kita membaca doa bersama mereka hanya bisa sekedar menyebutkan di bagian awalnya saja atau di bagian akhirannya saja.

4. Mahasiswi KKN sudah bisa mengenali sikap, sifat serta karekter dari masingmasing peserta dauroh.

5. Santri perlahan membuka diri dan mulai akrab kepada mahasiswa KKN.

6. Interaksi dan komunikasi dari mahasiswi KKN dan peserta dauroh mulai berjalan baik bahkan sampai kegiatan telah selesai.

\section{KESIMPULAN}

Program pengabdian pada masyarakat yang diadakan oleh STIBA Makassar dengan tema Gerakan Cinta Al-Qur'an menjawab dan memberikan dampak yang positif kepada masyarakat, terutama ibu-ibu yang tidak sempat belajar Al-Qur'an dengan sebab bekerja. Hal lain juga berdampak pada anak-anak yang telah mengikuti kegiatan ini, tampak di antara mereka merasa senang dan bergembira pada saat belajar dan menghafal doa-doa dan surah-surah pendek. Hal ini diharapkan bisa menjadi bekal bagi mereka pada saat mereka dewasa. Hal ini tentu pula menjadi langkah yang baik untuk menjadikan masyarakat Desa Kolaling dekat dan cinta dengan Al-Qur'an.

\section{DAFTAR PUSTAKA}

Aswar, Aswar, and Rosmita Rosmita. "Festival Anak Saleh Di Desa Leang-Leang Kabupaten Maros." WAHATUL MUJTAMA': Jurnal Pengabdian Masyarakat 1, no. 1 (2020): 54-66. https://doi.org/10.36701/wahatul.v1i1.137.

Enrekang, STKIP Muhammadiyah. "Pelatihan Dan Pengajaran Baca Tulis Al- Qur ' an Pada TK -TPA At-Taqwa dalam Mengatasi Buta Aksara Qur' an di Kelurahan Kambiolangi Ismail” 1, no. 1 (2019): 21-27.

Putri, Sri Ujiana, and Aswar Aswar. "Implementasi Pendidikan Masyarakat Berbasis Masjid untuk Muslimah di Desa Mattoanging Kabupaten Maros." WAHATUL MUJTAMA': Jurnal Pengabdian Masyarakat 1.2 (2020): 129141.

Santi Sarni, Jujuri P. Dunia, Hijrayanti Sari. Gemar Qur'an, “Gerakan ... 
- JuRnal W WAHATUL MUJTAMA': Jurnal Pengabdian Masyarakat

WAHATUL Vol. 2, No. 1 (2021): Hal. $41-48$

MUJTAMA'

JURNAL PENGABDIAN

Website: https://journal.stiba.ac.id

ISSN: 2723-6013 (Online)

Tempo, Rachmat Bin Badani, and Khaerul Aqbar. "Ikhtiar Mahasiswa KKN STIBA Makassar dalam Pembentukan Akhlak Qur'ani Masyarakat Desa Balassuka Kabupaten Gowa." WAHATUL MUJTAMA': Jurnal Pengabdian Masyarakat 1.1 (2020): 90-115.

Hasanah, Uswah, et al. "PKM Pembinaan Taman Baca Al Quran Dalam Pembelajaran Tahsin Tilawah Di Kelurahan Sari Rejo Medan Polonia." IHSAN: Jurnal Pengabdian Masyarakat 2.1 (2020): 101-111.

Santi Sarni, Jujuri P. Dunia, Hijrayanti Sari. Gemar Qur'an, “Gerakan ... 